\title{
A DESCRIPTIVE STUDY TO ASSESS THE PRACTICE OF BREASTFEEDING AMONG PRIMI MOTHERS AT SELECTED HOSPITALS, PUDUCHERRY
}

\author{
*Mrs. V. Revathy
}

\section{INTRODUCTION \\ "There is no substitute for mother's love, there is no substitute for mothers milk."William Gouge}

The birth of the baby is an important event in the family. It is therefore important for the mothers to have a healthy baby. Breast milk is the best food for the babies as breast fed babies are healthier than formula fed babies Breast milk is a species specific complete food. It is easily digested and well absorbed by the newborn. Protection against infection and facilitate mother infant bonding and promotes better brain growth. For the mother breast feeding helps in involution of uterus, delays pregnancy and lower risk of breast and ovarian cancer. In countries with high infant mortality rate, artificially fed infants are 14 times more likely to die of diarrhea than are breast fed and 4 times more likely to die of pneumonia. Artificially fed infants are 5 times likelyto require hospitalization for treatment of infectionsglobally, less than $40 \%$ of infants under six months of age are exclusively breastfed.

\section{STATEMENT OF THE PROBLEM:}

A descriptive study to assess the practice of breastfeeding among primi mothers at selected hospitals, Puducherry

\section{OBJECTIVES}

1) To assess the practice of breastfeeding among primi mothers
2) To determine the association between the practice of breastfeeding among primi mothers with selected demographic variables

\section{ASSUMPTIONS}

$\checkmark$ Primi mothers are not aware of proper technique of breast feeding

$\checkmark$ primi mothers will vary in breastfeeding practices according to socio- cultural factors

\section{MATERIALS AND METHODS}

\section{Research approach}

A descriptive approach was considered most suitable for the study, as the aim was to assess the practice of breast feeding among primipara mothers.

\section{Research design}

Non experimental descriptive survey research design

\section{Settings of the study}

The study was conducted in post natal ward at selected hospitals, Puducherry

\section{Population}

Post natal mothers

\section{Sampling technique}

In this study Purposive sampling technique was used

\section{*M.Sc., Nursing II year, Vinayaka Missions College of Nursing, Puducherry.}


Samples \& Sample size

In this study 30 Primipara mothers were selected who fulfil the inclusion criteria.

\section{CRITERIA FOR SELECTION OF SAMPLE}

a) Inclusion criteria:

$\checkmark$ Primipara mothers who can understand either English or tamil language.

$\checkmark$ Primipara mothers who are willing to participate for study

b) Exclusion criteria:

$\checkmark$ mothers who have undergone caesarean section

$\checkmark$ mothers who are not available at the time of study

\section{INSTRUMENTS USED FOR THE STUDY}

Based on the objectives of the study observational checklist was developed to assess the practice regarding technique of breastfeeding among primi mothers.

\section{Description and development of the tool}

In this study the data collection instrument consists of two sections. They are

\section{Section A:}

Itconsists of demographic variables which includes age, educational status, type of family, religion, area of residence, occupation, family monthly income and source of information on breastfeeding.

\section{SectionB:}

Assessment of practice regarding technique of breastfeeding. This section was observed using a checklist consists of 15 questions to assess the practice of primi mothers regarding technique of breastfeeding. Each question has "yes" or "no" response.For each correct response score 1 was given and for each incorrect response score 0 was given.

\section{MAJOR STUDY FINDINGS}

The Major findings are summarized as follows

\section{i) Description of demographic variables}

$\checkmark$ Higher percentage 14(47\%) of primi mothers regarding breastfeeding wasin the age group of 25-30 years.

$\checkmark$ Majority of primi mothers (30\%) had both primary and secondary education.

$\checkmark$ Majority of primi mothers 18 $(60 \%)$ belongs to nuclear family.

$\checkmark 19(73 \%)$ of the mothers belongs to Hindu,4(14\%) of the mothers belongs toChristian and 7(23\%) of the mothers belongs to Muslim.

$\checkmark$ Majority of primi mothers 21 $(70 \%)$ were from rural and $9(30 \%)$ were from urban community respectively.

$\checkmark$ Most of the primi mothers were homemakers15(50\%).

$\checkmark$ Monthly income of majority of primi mothers 14(47\%) were below Rs.5,000/-

$\checkmark$ Half of the primi mothers 15(50\%) had no previous informationon breast feeding. 


\section{ii. Practice of breast feeding}

$\checkmark 11(37 \%)$ of primi mothers had done appropriate level of breast feeding

$\checkmark$ The mean and standard deviation were 6 and and $19(63 \%)$ of primi mothers had done inappropriate level of breast feeding.

\subsection{5}

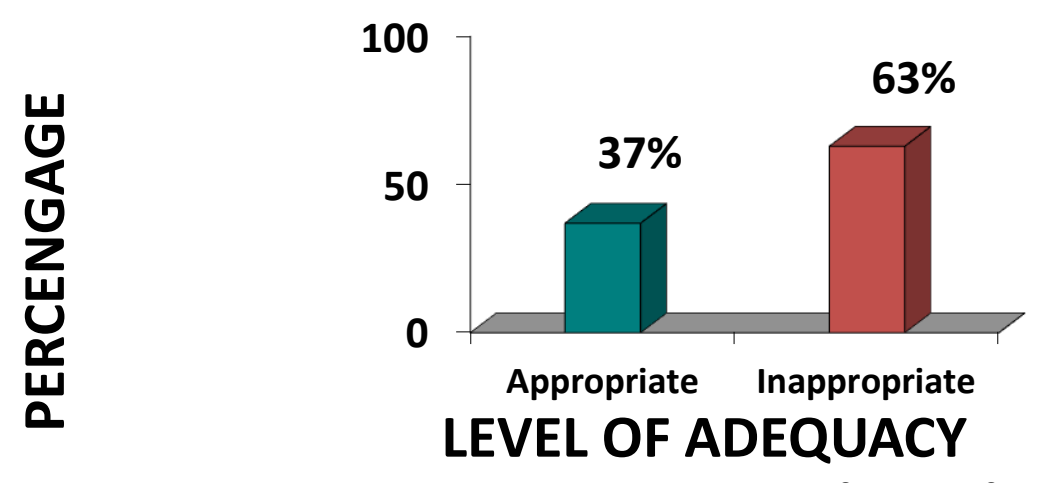

Bar diagram on percentage distribution of level of adequacy of breast feeding among Primi para mothers

iii) Association between practice of breast feeding and selected demographic variables

$\checkmark$ The study shows that there was statistically significant association between the practice of breastfeeding among primi mothers with selected demographic variables such as age, educational status, type of family, religion, area of residence, occupation, family monthly income and there was no association forprevious source of information.

\section{CONCLUSION:}

In this study,majority of primi mothers follow inappropriate level of breastfeeding practices. Statistically significant association was found between the practice of breastfeeding among primi mothers with selected demographic variables such as age, educational status, type of family, religion, area of residence, occupation, family monthly income and there was no association for previous source of information.

It indicates that the practice of breastfeeding technique have to be improved.To reinforce their practice,adequate health education and health awareness programmes will be more effective among primipara mothers.

\section{BIBLIOGRAPHY:}

Achar S. (2000). Text book of Pediatric. $6^{\text {th }}$ edition, Orient Long Man: Chennai.

BT Basavanthappa(2006).Midwifery and Reproductive health Nursing, New Delhi, Jaypee brothers. 
Ministry of Health and Family welfare Government of India, Basic newborn care and Resuscitation program training manual

Denise Polit, Cheryl Beck, (2006).Essentials of nursing research methods, appraisal and utilization. $6^{\text {th }}$ edt, London: Lippincott Williams and Wilkins.

Terri Kyle, (2008).Essentials of pediatric nursing. $4^{\text {th }}$ edt, New York: Wolters Kluwer.

\section{CASE SCENARIO KEY POINTS}

\section{Case scenario 1 Key Points:}

* Identify the normal and abnormal ECG

* Ask for the complaints

* Check the vitals for every $15 \mathrm{mts}$

* Follow the physician orders

* Continuous cardiac monitoring

* Send routine blood investigations

* Assess for ST elevation

* Monitor 12 leads ECG check for ECG changes

* Presence of ST changes indicates MI ,other changes indicates ACS

* Do cardiac enzymes investigation to rule out $\mathrm{MI}$

* If there is no ST changes with II and III Lead change the III and IV lead to right side to rule out Ventricular Fibrillation

\section{Case scenario 2Key points:}

* Checking of distal pulses

* Arterial line flushing

* Changing of AVP dressing

* Assess for complication

* Know the normal and abnormal $\checkmark A B P$ values

\section{Case scenario 3 Key points}

- Monitoring CVP

- Faulty practice

Case scenario 4 Key points

* Placement of Probe

* Position of the Finger 